\title{
3D models related to the publication: Neogene sloth assemblages (Mammalia, Pilosa) of the Cocinetas Basin (La Guajira, Colombia): implications for the Great American Biotic Interchange
}

\author{
Amson Eli ${ }^{1,2,3 *}$, Carrillo Juan David ${ }^{2}$, Jaramillo Carlos ${ }^{1}$ \\ ${ }^{1}$ Smithsonian Tropical Research Institute, Box 0843-03092, Balboa-Ancon, Panama \\ ${ }^{2}$ Paläontologisches Institut und Museum der Universität Zürich, Zürich, Switzerland 2, CH-8006 \\ ${ }^{3}$ Humboldt-Universität, AG Morphologie und Formengeschichte, Bild Wissen Gestaltung - ein interdisziplinäres Labor \& Institut für Biologie, \\ Berlin, Germany D-10115 \\ *Corresponding author: eli.amson1988@gmail.com
}

\section{Abstract}

The present 3D Dataset contains the 3D models analyzed in Neogene sloth assemblages (Mammalia, Pilosa) of the Cocinetas Basin (La Guajira, Colombia): implications for the Great American Biotic Interchange. Palaeontology. doi: 10.1111/pala.12244.

Keywords: Great American Biotic Interchange, Neotropics, palaeobiodiversity, Tardigrada, Ware Formation

Submitted: 2016-04-05, published online: 2016-06-08. doi: 10.18563/m3.2.1.e3

\begin{tabular}{|c|c|c|}
\hline Model IDs & Taxon & $\begin{array}{c}\text { Short } \\
\text { description }\end{array}$ \\
\hline $\begin{array}{c}\text { M3\#106_MUN } \\
\text { STRI } 12924\end{array}$ & $\begin{array}{c}c f . \\
\text { Nothrotherium }\end{array}$ & $\begin{array}{l}\text { Fragmentary } \\
\text { basicranium with } \\
\text { posterior portion } \\
\text { of the skull roof. }\end{array}$ \\
\hline $\begin{array}{c}\text { M3\#107_MUN } \\
\text { STRI } 16535\end{array}$ & $\begin{array}{l}\text { Scelidotheriinae } \\
\text { gen. et sp. indet. }\end{array}$ & $\begin{array}{l}\text { Complete left } \\
\text { ulna. }\end{array}$ \\
\hline
\end{tabular}

\section{INTRODUCTION}

We here present the surface models of two specimens of sloths (Mammalia, Tardigrada) coming from the Late Pliocene Ware Formation (Cocinetas Basin, La Guajira, Colombia, see Table 1). Along with three additional sloth taxa found in the same Formation, these specimens document the great diversity of this Neotropical locality. Furthermore, they represent a sloth assemblage from a locality just a few hundred thousand years older than the classically recognized first main pulse of the Great American Biotic interchange, that is located few hundred kilometers away from the Isthmus of Panama, the most likely route of migration of terrestrial taxa. These specimens are hence important in the understanding of this major paleobiogeographic event.

\section{METHODS}

The fossil specimens were scanned with an Artec Spider 3D using the geometry and texture tracking setting and processed with Artec Studio 9 Education Software (Artec 3D). The 3D surfaces scans were aligned semi-automatically with Artec
Studio 9. The aligned scans were converted into a single coordinate system using the Global Registration function (texture and geometry) and then fused into a single 3D model with the Fast Fusion function of Artec Studio. The 3D surface models are provided in .ply format, and can therefore be opened with a wide range of freeware.

\section{ACKNOWLEDGEMENTS}

Smithsonian Tropical Research Institute; Alexander von Humboldt Foundation; Swiss National Fund, grant number to $\mathrm{M}$. R. Sánchez-Villagra: SNF 31003A-149605; National Geographic Society; Anders Foundation; Gregory D. and Jennifer Walston Johnson; National Science Foundation, grant number: EAR 095767.

\section{BIBLIOGRAPHY}

Amson, E., Carrilo, J.D., Jaramillo, C. 2016. Neogene sloth assemblages (Mammalia, Pilosa) of the Cocinetas Basin (La Guajira, Colombia): implications for the Great American Biotic Interchange. Palaeontology. doi: 10.1111/pala.12244 